\title{
Location Analysis of Freight Distribution Terminal of Jakarta City, Indonesia
}

\author{
Nahry $^{1^{*}}$, Tjahjono, T. ${ }^{1}$ Iriantika, B. ${ }^{1}$, and Semedi, J.M. ${ }^{2}$
}

\begin{abstract}
Currently Jakarta has two freight terminals, namely Pulo Gebang and Tanah Merdeka. But, both terminals are just functioned for parking and have not been utilized properly yet, e.g. for consolidation. Goods consolidation, which is usually performed in distribution terminal, may reduce number of freight flow within the city. This paper is aimed to determine the best location of distribution terminal in Jakarta among those two terminals and two additional alternative sites, namely Lodan and Rawa Buaya. It is initialized by the identification of important factors that affect the location selection. It is carried out by Likert analysis through the questionnaires distributed to logistics firms. The best location is determined by applying Overlay Analysis using ArcGIS 9.2. Four grid maps are produced to represent the accessibility, cost, time, and environment factors as the important factors of location. The result shows that the ranking from the best is; Lodan, Tanah Merdeka, Pulo Gebang, and Rawa Buaya.
\end{abstract}

Keywords: Best location; consolidation; freight distribution terminals.

\section{Introduction}

Goods consolidation is an effort to reduce operational vehicles by carrying the same goods by combining some commodities in the same destination or near one to others [1]. Jakarta as the capital city of Indonesia has a great role in Indonesia economics activity and is one of important nodes of national economics corridor. Freight movements exist not only due to the internal economic activities of the city, but also due to the intercity freight movements. The intercity freight movements have increased the burden of city freight movements. Meanwhile, freight traffic in Jakarta now is increasing rapidly. In order to accommodate the freight activities, government of Special Capital Region of Jakarta developed two freight terminals, namely Pulo Gebang Terminal and Tanah Merdeka Terminal. However, both terminals have not been functioned properly as freight terminals; they are just being utilized as parking lots for trucks. Likely, due to their strategic location, both terminals are very potential to serve as consolidation terminals, besides two other sites, namely Rawa Buaya and Lodan.

\footnotetext{
${ }^{1}$ Department of Civil Engineering, Faculty of Engineering, Universitas Indonesia, Depok, INDONESIA

2 Department of Geography, Faculty of Mathematics and Natural Science,Universitas Indonesia, Depok, INDONESIA

* Corresponding authour; e-mail: nahry@eng.ui.ac.id
}

Note: Discussion is expected before June, $1^{\text {st }} 2016$, and will be published in the "Civil Engineering Dimension" volume 18, number 2, September 2016.

Received 24 October 2015; revised 13 January 2016; accepted 16 March 2016
Rawa Buaya was a bus terminal and currently utilized as bus parking lot, and Lodan is a container yard and train garage. The aim of this paper is to determine the best location of freight distribution terminal in Jakarta among those four site alternatives.

\section{Freight Terminal and Istribution Center}

Each country has its own definition on distribution center (DC), depends on the approach, policy, and factual conditions (geographic, climate, and typology). Definition and understanding of DCis related to the use of freight terminals. Browne. et al [2] definitions of DC is a logistic facility located in strategic area, to serve city center, thewhole city, or specific location; with goods consolidations. Lewis et al. [1], defined goods consolidations as the way of reducing operational vehicles with the same commodity carried, and combining those similar commodities at the same direction or destinations. Furthermore, those previous definitions are further elaborated in association with the goods consolidation concept. It defines DC as a center for goods distribution, located near the city center, shopping center, or construction site, where goods are consolidated based on the same destinations. From those definitions it is shown that there is similar meaning between distribution center and consolidation center. Both terminologies, i.e. distribution center and consolidation center focus on the issue of location of the terminal. However, Lewis et al. [1] emphasized their definition on the consolidation function of terminal. Marinov [3] added explanation for Freight Distribution Center as the activity center for fulfill market's demand in pickup-to-distribute on specified connectivity. 
Definition of distribution center in this paper refer to Munuzuri [4], it explain how the freight terminal's function can be optimize to Distribution Center by adding some activity for basic function of Freight Terminal. Munuzuri [4] named freight terminal as the city terminal. In order to prevent the goods movement problems, freight terminal can be related to public infrastructure management. Public infrastructure management can be manage by two approaches, first one is to build an infrastructure physically; or second is adapting the existing infrastructure to serve inner city's logistic activities.

The success or failure of private and public sector facilities depends in part on the locations chosen for those facilities [5]. Location decisions arise in a variety of public and private sector problems. Government needs to determine locations for bases for emergency highway patrol vehicles, location of fire stations, and ambulances. Private company must locate offices, plants, distribution centers, and retail outlets.

Some factors should be taken into account to make decision on location, and they depend on the type of facility. In choosing the best location for housing, the important factors to be considered are convenience or accessibility, environment or exposure, and protection from externalities [6]. The most influencing factors in developing shop house business from the developers' point of view is financial aspect, market, location, and physical aspects, while the most influencing factors from the consumers' point of view are price and product factors [7].

In order to determine the best location of freight distribution terminal, firstly we have to define factors that affect the location selection. Synthesis of location factors of freight distribution terminal discussed in the previous studies is summarized in Table 1.

\section{Method}

The best location of freight distribution terminal is determined through two steps of analysis, namely the determination of the important factors that affect the location selection, and the analysis to find ranking of the alternative sites.

Determination of location factors is carried out through the qualitative approach, by conducting questioners to the current freight terminals users (i.e. Tanah Merdeka Terminal and Pulo Gebang Terminal) in order to analyze their perspective on the importance of the factors in term of location selection. The analysis makes use of Likert scale, a psychometric scale to measure respondent's opinion about any issue [8].
Table 1. Location Factors of Freight Distribution Terminal

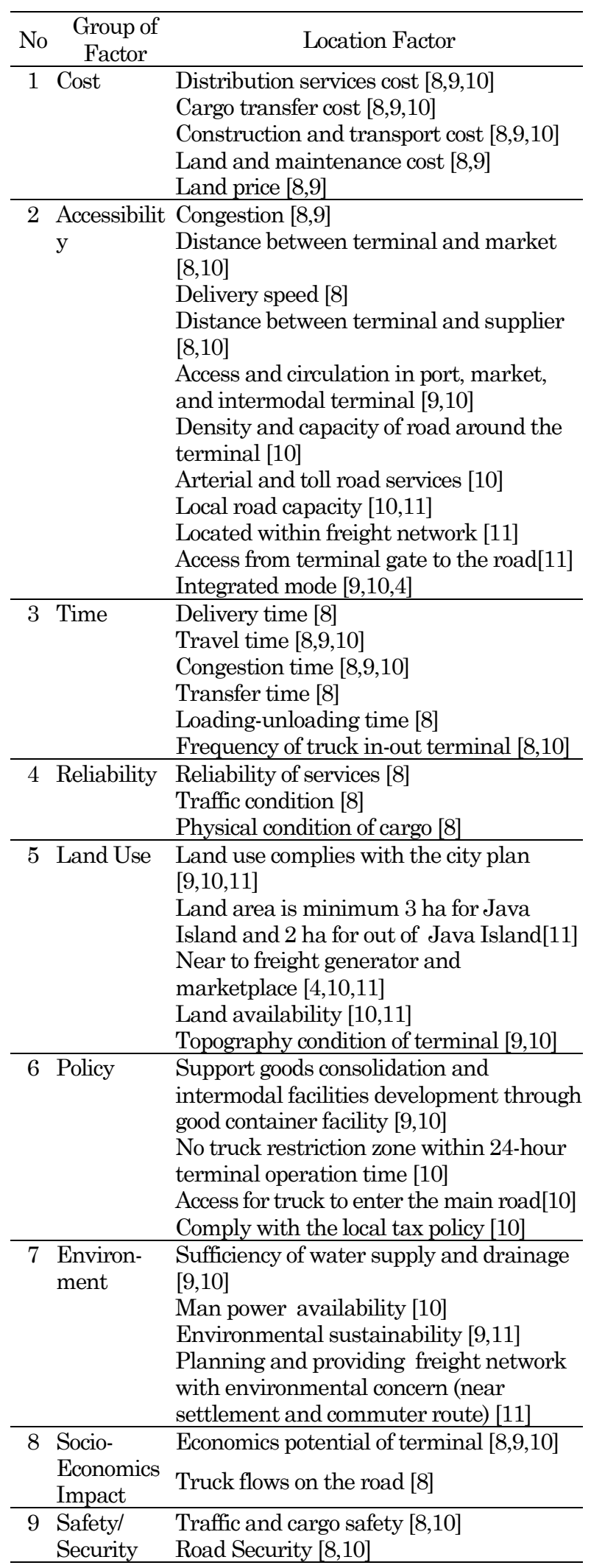

Respondents are chosen by purposive sampling methods due to the limited number of freight terminal users. Twenty respondents are chosen representing several national logistics firms in Greater Jakarta. 
The firms included in the survey are as follows:

1. Logistics firm that has experiences of using distribution center, or has intention to use it.

2. Logistics firm that deals with consumer goods (retailer needs) and industrial goods. It includes all types of goods except liquid, hazardous, and raw foods materials.

3. Logistics firm whose scope of services is in national level.

All the location factors identified in the literature reviews (seeTable 1) are put in the questionnaire, and the respondents are asked to give their opinion on those factors using 5 scale of Likert as follows: 1 for no influence; 2 for fair influence; 3 for influence; 4 for very influence; and 5 for extreme influence. The final weight of each factor is calculated using Equation 1 as follows [12]:

$W=\frac{\sum_{S}\left(T P_{S}\right)}{N}$

where:

$W=$ Weight of each factor

$T=$ Number of respondent choosing scale- $s$

$P_{s}=$ Likert scale- $s$

$N=$ Number of respondent

$S=$ Number of Likert Scale

The number of factors considered in the questionnaire is 42 . In order to simplify further analysis, the factors are reduced by classifying them into two classes, namely primary factors and supporting factors. Only the primary ones are taken into account in the further analysis. Both classes are distinguished using their weight resulted from Likert analysis. Interval range of the weight of both classes is determined by Equation 2 as follows:

$r=\frac{(X-Y)}{n}$

in which $r$ is the range of interval of a class, $n$ is the number of class, $X$ is the maximum weight, and $Y$ is the minimum weight.

Furthermore, the determination of primary location factors is followed by the analysis to rank the four alternative sites. It is carried out by applying weighted overlay analysis, a method of spatial analysis whose ability is to combine several different Geographic Information System (GIS) layers in order to enable complex queries to be performed as its purpose. Here, its purpose is to find the best location, as well as the ranking of the alternative sites of the freight distribution center. The analysis is supported by ArcGIS software [13].

Overlay analysis constitutes two types of map, namely basic map and grid map. Basic map is a raster map that represents values of variable associated to the location factor of each spatial unit on the map. The basic map is generated using the values of variable which come from primary survey or secondary data published by the associated authority. For example, the basic map of "distribution service cost" indicates the cost to serve goods distribution in all spatial units existed on the map. The data comes from the primary survey. Since the spatial unit used in the overlay analysis is unit of district (Kecamatan), hence the data of district where the alternative site is located will represent data of the alternative site of terminal. In order to synchronize various units of the basic maps, all the data on each basic map are classified into some levels, and the ArcGIS generates certain value to represent such levels in further analysis. Hence, each spatial unit in study area has its own level of factor that associated to the basic map it represents. The number of level of each basic map is defined by arbitrary judgement, which depends on the range of value of the variable. As the range is quite big, it is better to set more levels to find more precision on further analysis. For example, the authors use three levels of data, i.e. low, medium, and high for basic map of 'Cargo Transfer Cost'.

Furthermore, the grid map is formed by overlaying some basic maps into one map based on certain theme. Themes for grid maps are taken from group of location factors stated in column 2 of Table 1 . Hence, there exists grid map of Cost, Accessibility, Time, Environment, and Safety and Security. The overlaying of basic maps is plausible due to the substitution of the original 'unit' of basic map into 'level' as described above. For the factors that positively support the success of terminal operation (e.g. 'access from terminal gate to the road'), the higher the level on basic map the more suitable the site would be, and vice versa (e.g. 'travel time' factor)= Hence, in the overlay of basic maps, the positive factors are indicated by positive value, whereas the negative factors are indicated by negative value.

Lastly, all grid maps are superimposed to form the final map by applying the Likert weights that correspond to each grid maps. The final map shows the suitability of each spatial unit to be a distribution terminal. In this case, suitability is classified into three levels, namely low, fair, and high. Similar to the basic map and grid map, ArcGIS generates certain value, i.e. suitability weight, to each level of final map. In order to find the final result of the overlay analysis, ArcGIS measures the proportion of area corresponds to each level. Afterward, the proportion of area is multiplied by the associated mid value of suitability weight to find suitability value, and then the suitability values of the three levels are summed up to find the total suitability of each alternative site. The higher the suitability value, the better the site to be chosen as distribution terminal. 


\section{Result and Discussion}

\section{Analysis of Location Factors of Freight Distribution Terminal}

The result of Likert analysis that generates the location factors with their weight is shown in Table 2.

Table 2. Result of Likert Analysis

\begin{tabular}{|c|c|c|}
\hline No & Location Factor & Weight \\
\hline 1 & Distribution services cost & 10.0 \\
\hline 2 & Cargo transfer cost & 15.4 \\
\hline 3 & Construction and transport cost & 6.4 \\
\hline 4 & Land and maintenance cost & 6.2 \\
\hline 5 & Land price & 6.8 \\
\hline 6 & Congestion & 11.6 \\
\hline 7 & Distance between terminal and market & 14.6 \\
\hline 8 & Delivery speed & 7.6 \\
\hline 9 & Distance between terminal and supplier & 12.0 \\
\hline 10 & Access and circulation in port, market and intermodal terminal & 13.4 \\
\hline 11 & Density and capacity of road around the terminal & 12.4 \\
\hline 12 & Arterial and toll road services & 16.8 \\
\hline 13 & Local road capacity & 14.8 \\
\hline 14 & Located within freight network & 16.6 \\
\hline 15 & Access from terminal gate to the road & 15.4 \\
\hline 16 & Integrated mode & 11.4 \\
\hline 17 & Delivery time & 8.0 \\
\hline 18 & Travel time & 11.8 \\
\hline 19 & Congestion time & 8.0 \\
\hline 20 & Transfer time & 7.6 \\
\hline 21 & Loading-unloading time & 11.6 \\
\hline 22 & Frequency of truck in-out terminal & 12.0 \\
\hline 23 & Reliability of services & 9.8 \\
\hline 24 & Traffic condition & 7.6 \\
\hline 25 & Physical condition of cargo & 7.2 \\
\hline 26 & Land use complies with the city plan & 8.0 \\
\hline 27 & Land area is minimum 3 ha for Java Island and 2 ha for out of Java Island & 6.6 \\
\hline 28 & Near to freight generator and marketplace & 11.6 \\
\hline 29 & Land availability & 6.4 \\
\hline 30 & Topography condition of terminal & 8.6 \\
\hline 31 & Support goods consolidation and intermodal facilities development through good container facility & 10.2 \\
\hline 32 & No truck restriction zone within 24-hour terminal operation time & 11.6 \\
\hline 33 & Access for truck to enter the main road & 7.6 \\
\hline 34 & Comply with the local tax policy & 6.6 \\
\hline 35 & Sufficiency of water supply and drainage & 11.6 \\
\hline 36 & Man power availability & 6.2 \\
\hline 37 & Environmental sustainability & 7.0 \\
\hline 38 & $\begin{array}{l}\text { Planning and providing freight network with environmental concern (near settlement and commuter } \\
\text { route) }\end{array}$ & 14.2 \\
\hline 39 & Economics potential of terminal & 6.6 \\
\hline 40 & Truck flows on the road & 8.8 \\
\hline 41 & Traffic and cargo safety & 11.4 \\
\hline \multirow[t]{3}{*}{42} & Road Security & 10.8 \\
\hline & Total index of variable & 428.8 \\
\hline & Average index of variable & 10.2 \\
\hline
\end{tabular}

Based on the highest weighted location factor (i.e. 16.8) and the lowest weighted location factor (i.e. 6.2), the interval ( $r$ ) for each class of factor is 5.3, giving the supporting factors as all location factors with weighted Likert scale below 11.5, and the primary factors above 11.5 (>11.5). The supporting factors has 24 factors, and the primary factors has 17 factors. The analysis only considers the primary factors (Table 3). All factors that represent the safety and security are included in the supporting factors; hence, those factors are discarded in further analysis. 


\section{Overlay Analysis of the Alternative Sites}

In the establishment of the basic maps of all factors, due to the complexity of data acquiring of the basic map, the authors use same basic map to represent several factors whose spatial characteristics are slightly similar. As the most representative factor, the biggest weight of such factors is chosen to designnate the weight of such basic map. For example, "Near to freight generator and marketplace" and "Distance between terminal and market" factor are represented by one basic map, i.e. "Map of distance between terminal and market", by designating the weight of 14.6 for such map (see Table 3). Accordingly, the classification of group of factor in the overlay analysis is slightly changed to justify the availability of basic map. Afterward, based on the Likert analysis, there are only four grid maps that should be considered in the GIS analysis; those are Cost, Accessibility, Time, and Environment.

The factors and their groups of factor, as well as the associated basic map and grid map that are used in the overlay analysis are described in Table 3, and the mapping of location factors and the associated maps is shown in Figure 1. The basic maps as well as grid maps are shown in Figure 2a 2j and Figure 3a 3d, respectively. The levels of each basic map as well as the ones of grid map are indicated in the legend of the map, and to ease the interpretation of the map, each level of the all maps is represented by certain color. Furthermore, the final map that shows the overlay analysis result is shown in Figure 4.

The total matching value of each site is summarized in Table 4. Based on the total value of suitability of all the alternative sites, the ranking of the sites (from the best one) is as follows: 1. Lodan; 2. Tanah Merdeka; 3. Pulo Gebang, and 4. Rawa Buaya.

As the location whose total value of suitability is the highest, Lodan Terminal becomes the most suitable location for the distribution terminal. In fact, Lodan is located in the middle of east-west Jakarta highway corridor so travel time to reach this site from all directions is relatively less. Lodan is also located in the center of industrial sites and it has good access to toll road and arterial road, as well as Tanjung Priok Port. It is indicated by the dominance of quite high level of suitability of the Grid Map of Cost and Accessibility at Lodan area.

Table 3. Factor, Sub Factor and Map on the Overlay Analysis

\begin{tabular}{|c|c|c|c|c|c|}
\hline $\begin{array}{l}\text { Group of } \\
\text { Factor }\end{array}$ & Factor & $\begin{array}{l}\text { Weight of } \\
\text { Factor }\end{array}$ & Basic Map & $\begin{array}{l}\text { Weight of } \\
\text { Basic Map }\end{array}$ & Grid Map \\
\hline Cost & Cargo transfer cost & 15.4 & Map of Cargo Transfer Cost & 15.4 & $\begin{array}{l}\text { Map of Cost } \\
\text { Factor }\end{array}$ \\
\hline \multirow{13}{*}{ Access } & Congestion & 11.6 & Map of congestion & 14.2 & Map of \\
\hline & Frequency of truck in-out terminal & 12.0 & & & Accessibility \\
\hline & $\begin{array}{l}\text { No truck restriction zone within } 24 \text { - } \\
\text { hour terminal operation time }\end{array}$ & 11.6 & & & Factor \\
\hline & $\begin{array}{l}\text { Density and capacity of road around } \\
\text { the terminal }\end{array}$ & 12.4 & & & \\
\hline & $\begin{array}{l}\text { Planning and providing freight } \\
\text { network with environmental } \\
\text { concern (near settlement and } \\
\text { commuter route) }\end{array}$ & 14.2 & & & \\
\hline & $\begin{array}{l}\text { Distance between terminal and } \\
\text { market }\end{array}$ & 14.6 & $\begin{array}{l}\text { Map of distance between } \\
\text { terminal and market }\end{array}$ & 14.6 & \\
\hline & $\begin{array}{l}\text { Near to freight generator and } \\
\text { marketplace }\end{array}$ & 11.6 & & & \\
\hline & $\begin{array}{l}\text { Distance between terminal and } \\
\text { supplier }\end{array}$ & 12.0 & $\begin{array}{l}\text { Map of distance between } \\
\text { terminal and supplier }\end{array}$ & 12.0 & \\
\hline & $\begin{array}{l}\text { Access and circulation in port, } \\
\text { market and intermodal terminal }\end{array}$ & 13.4 & $\begin{array}{l}\text { Map of access and circulation } \\
\text { in port and intermodal }\end{array}$ & 16.6 & \\
\hline & Located within freight network & 16.6 & terminal & & \\
\hline & Arterial and toll road services & 16.8 & Map of arterial and toll road & 16.8 & \\
\hline & Local road capacity & 14.8 & level of service & & \\
\hline & $\begin{array}{l}\text { Access from terminal gate to the } \\
\text { road }\end{array}$ & 15.4 & $\begin{array}{l}\text { Map of access from terminal } \\
\text { gate to the road }\end{array}$ & 15.4 & \\
\hline \multirow[t]{2}{*}{ Time } & Travel time & 11.8 & Map of travel time & 11.8 & Map of Time \\
\hline & Loading-unloading time & 11.6 & Map of loading-unloading time & 11.6 & Factor \\
\hline Environment & $\begin{array}{l}\text { Sufficiency of water supply and } \\
\text { drainage }\end{array}$ & 11.6 & $\begin{array}{l}\text { Map of sufficiency of water } \\
\text { supply and drainage }\end{array}$ & 11.6 & $\begin{array}{l}\text { Map of } \\
\text { Environment } \\
\text { Factor }\end{array}$ \\
\hline
\end{tabular}




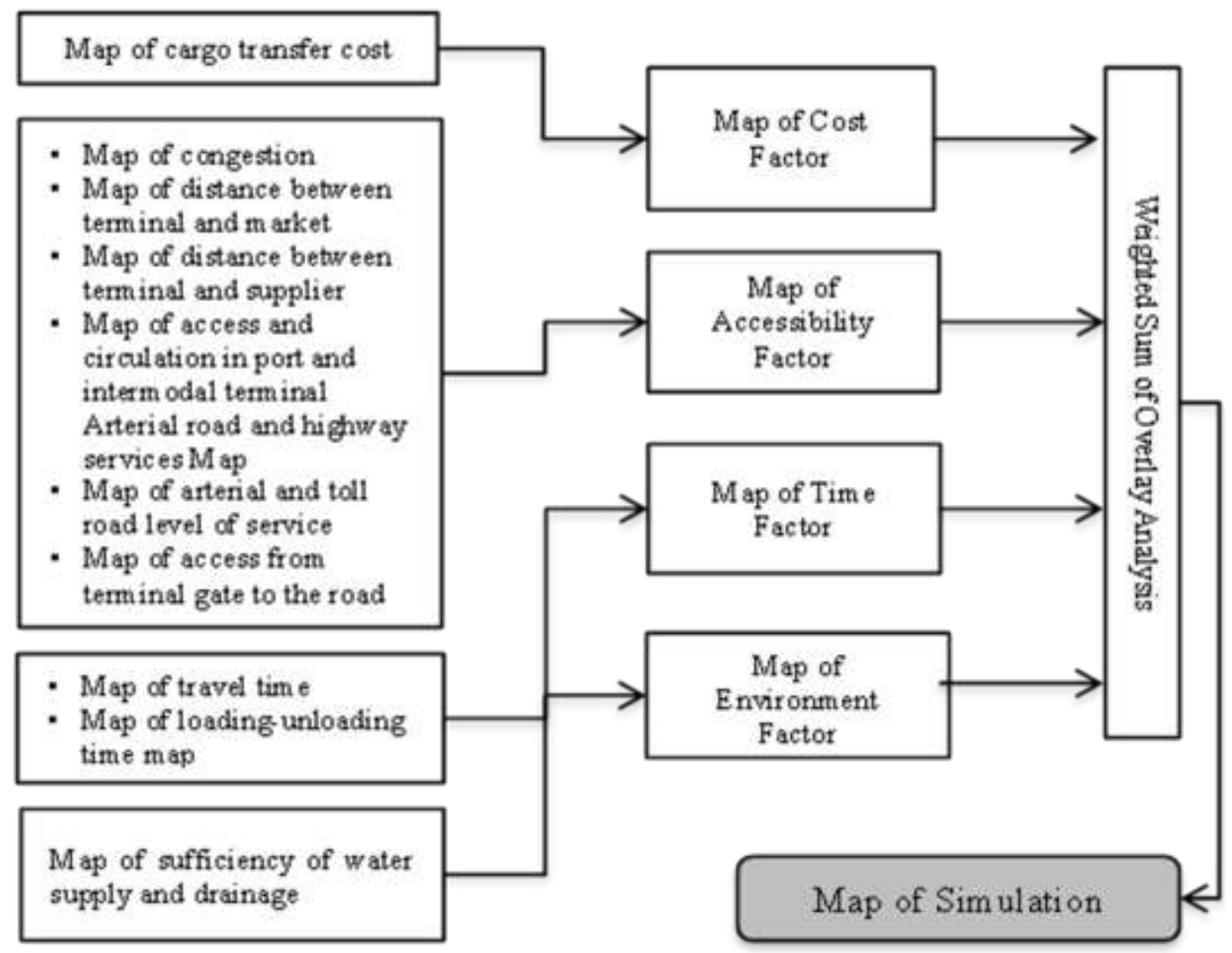

Figure 1. Mapping of the Overlay Analysis

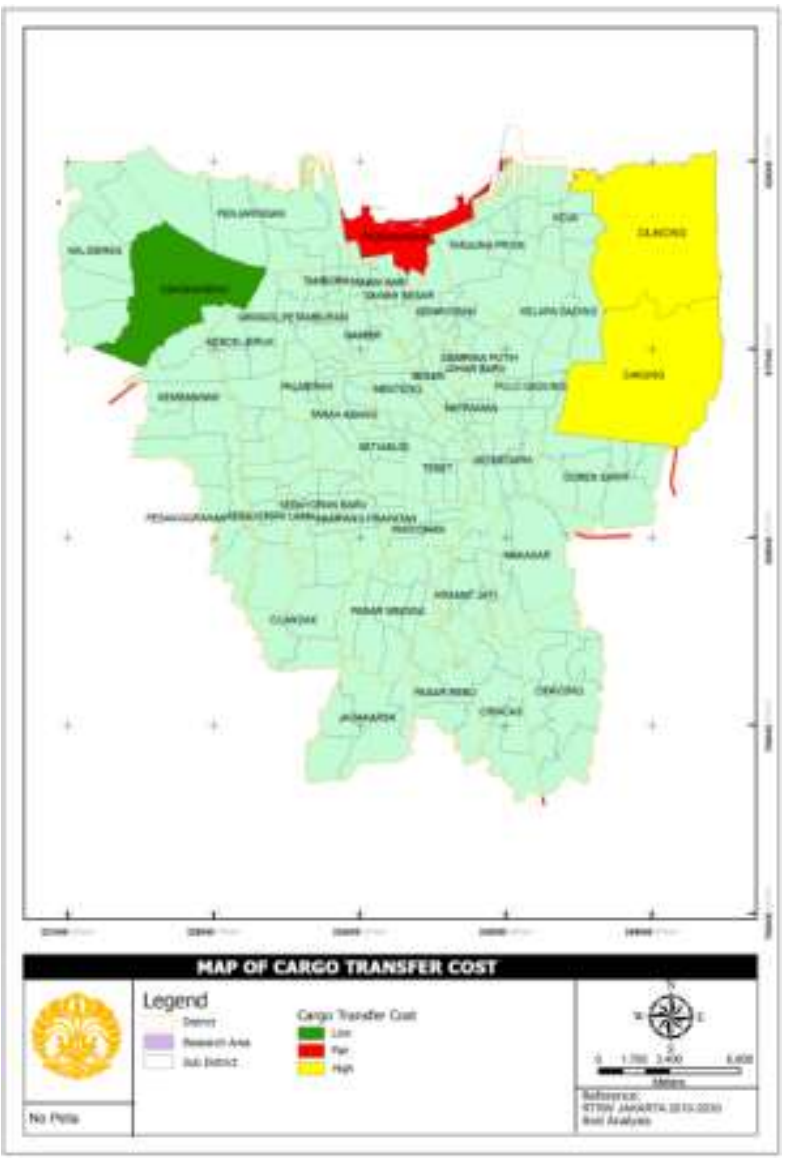

Figure 2a. Basic Map of Cargo Transfer Cost

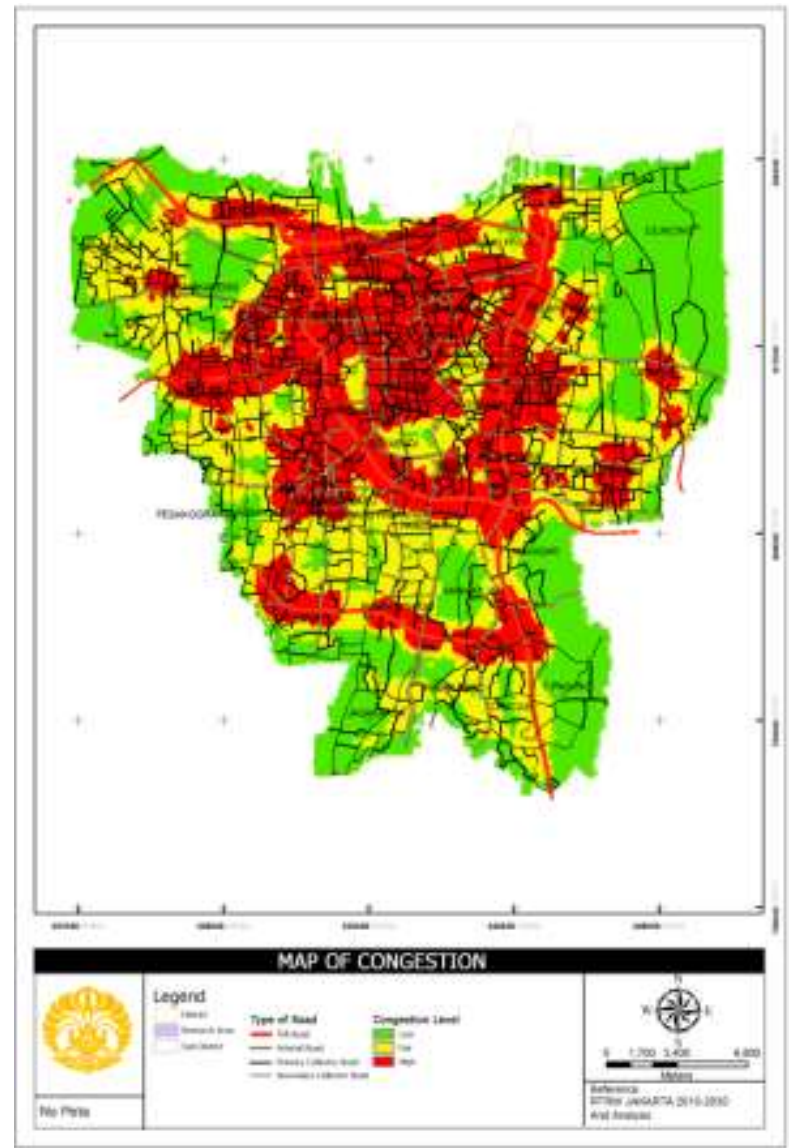

Figure 2b. Basic Map of Congestion 


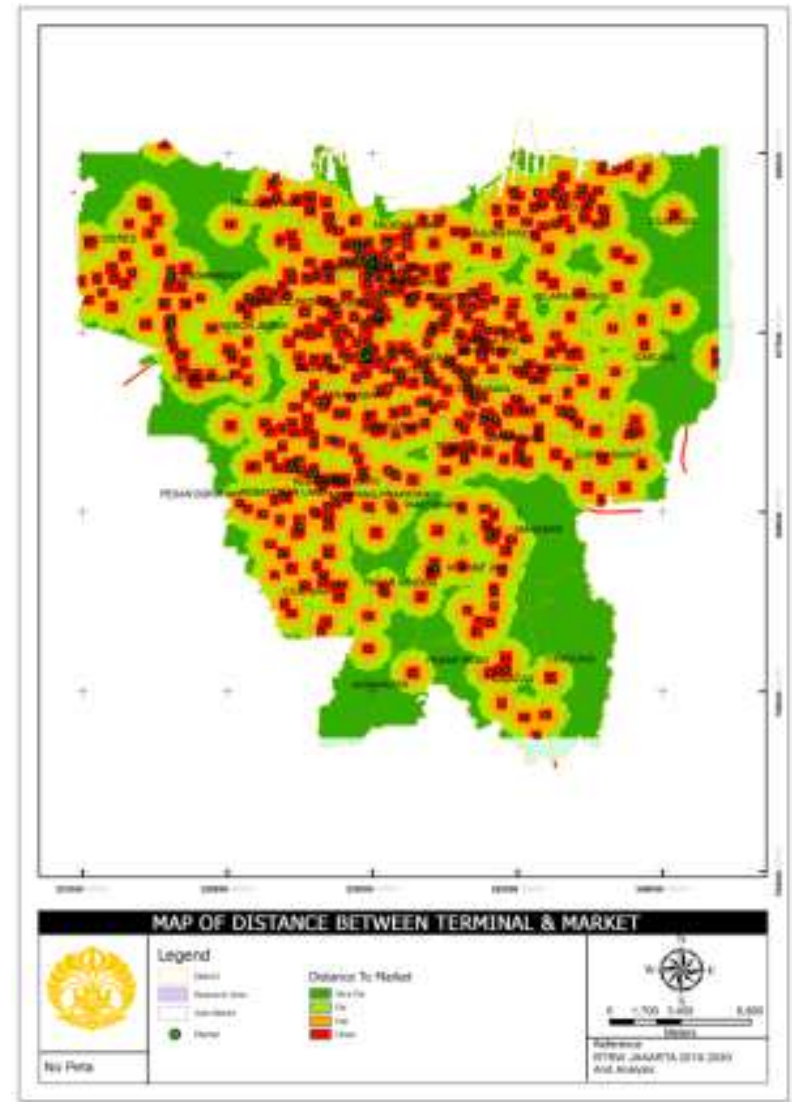

Figure 2c. Basic Map of Distance between Terminal and Market

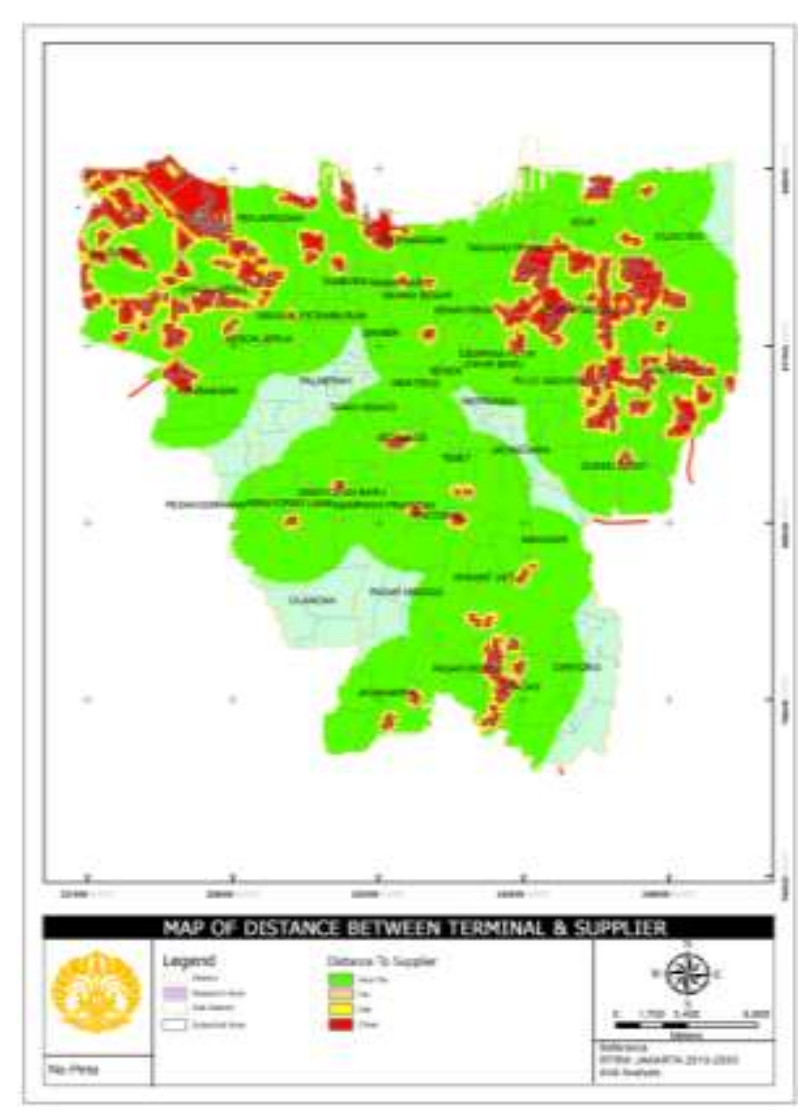

Figure 2d. Basic Map of Distance between Terminal and Supplier

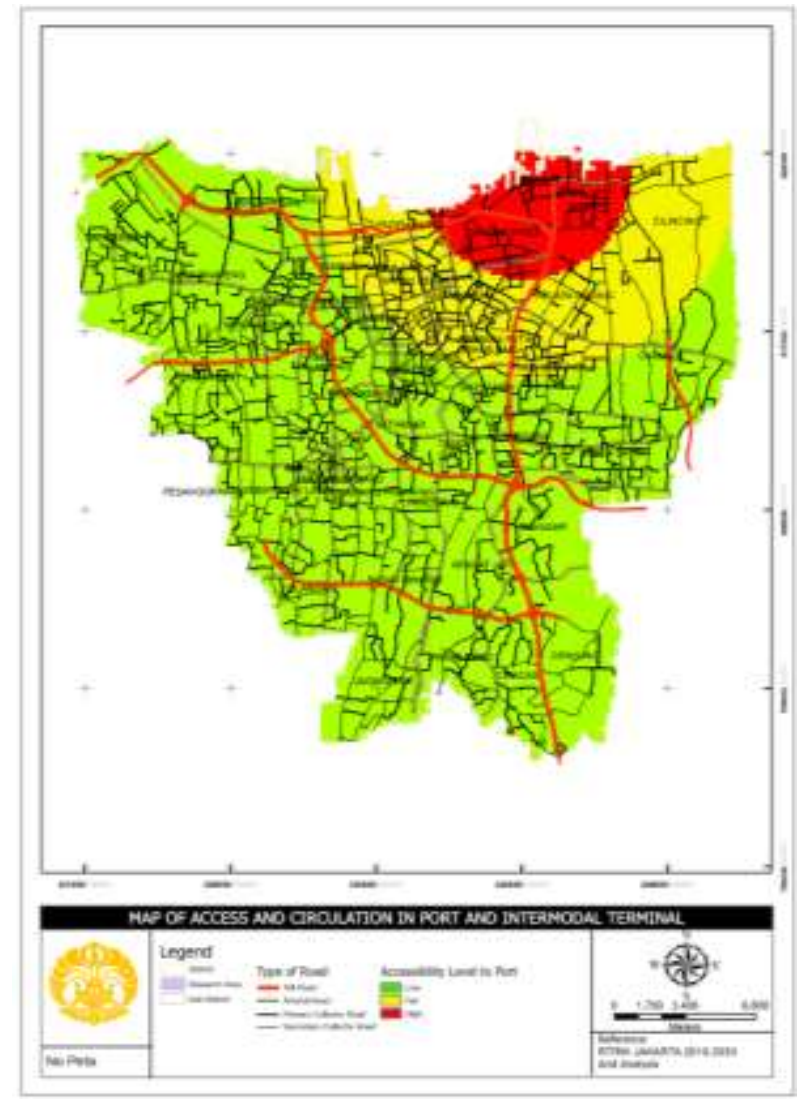

Figure 2.e Basic Map of Access and Circulation in Port and Intermodal Terminal

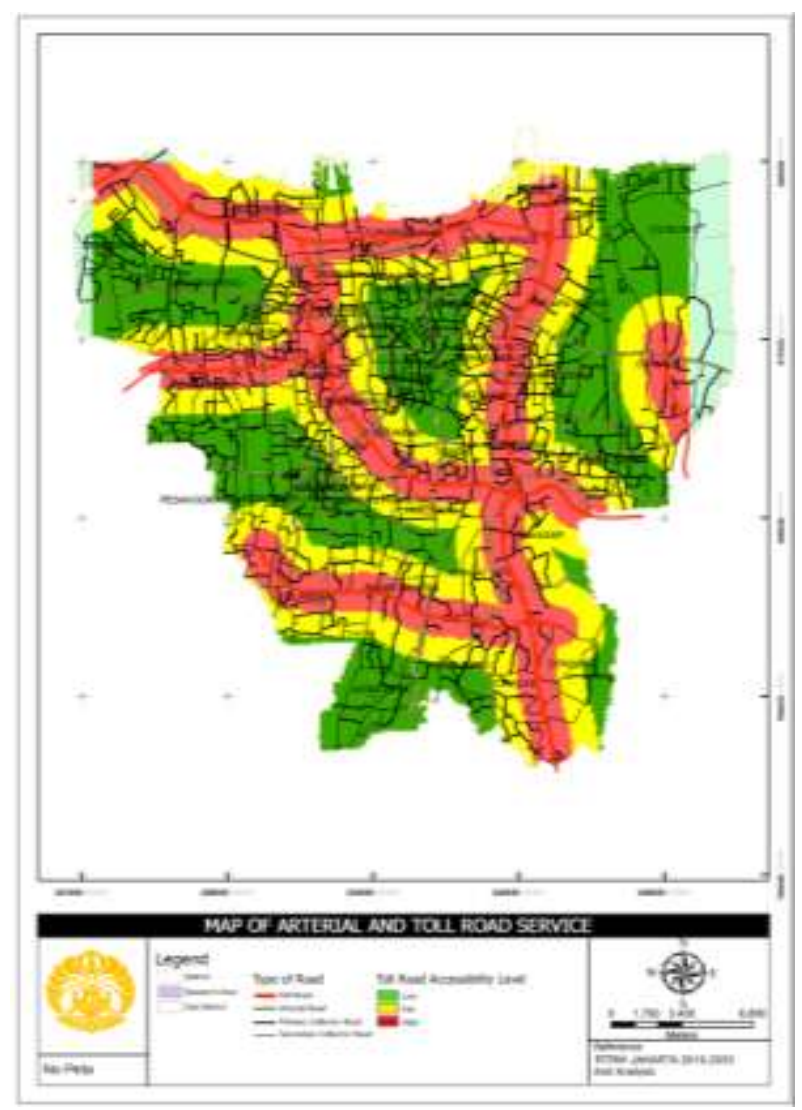

Figure 2.f Basic Map of Arterial and Toll Road Service 


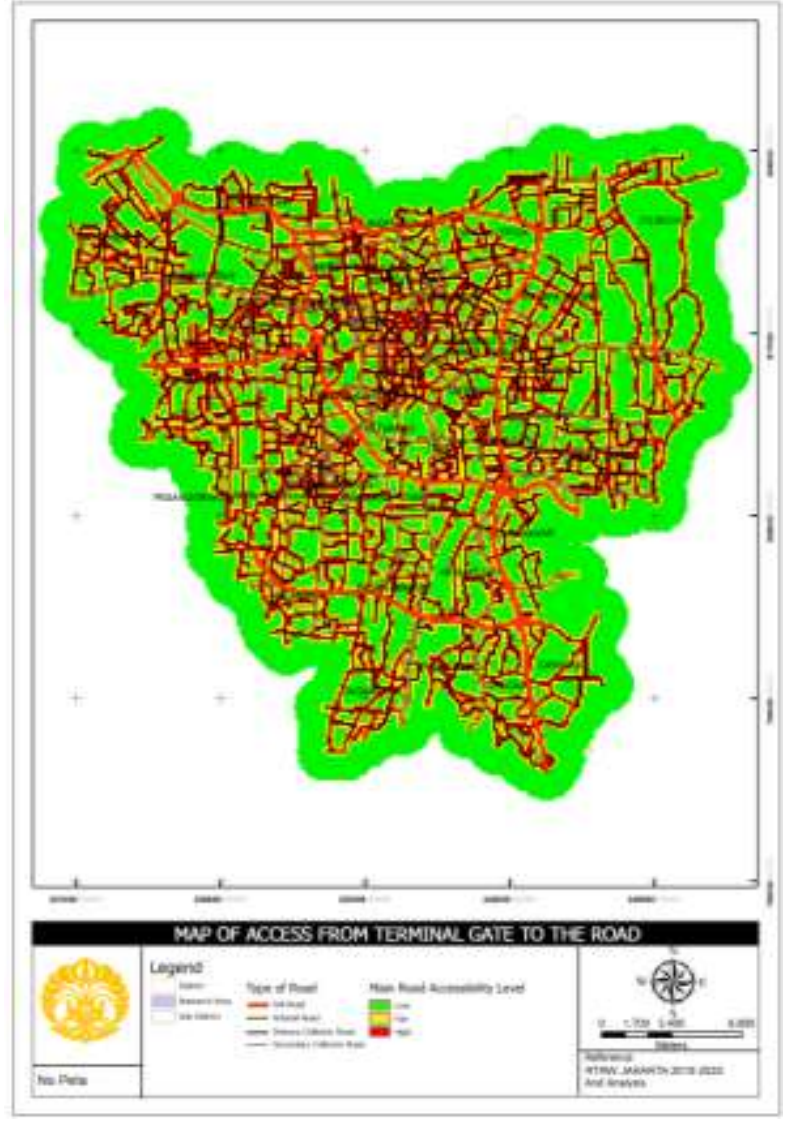

Figure 2.g Basic Map of Access from Terminal Gate to the Road

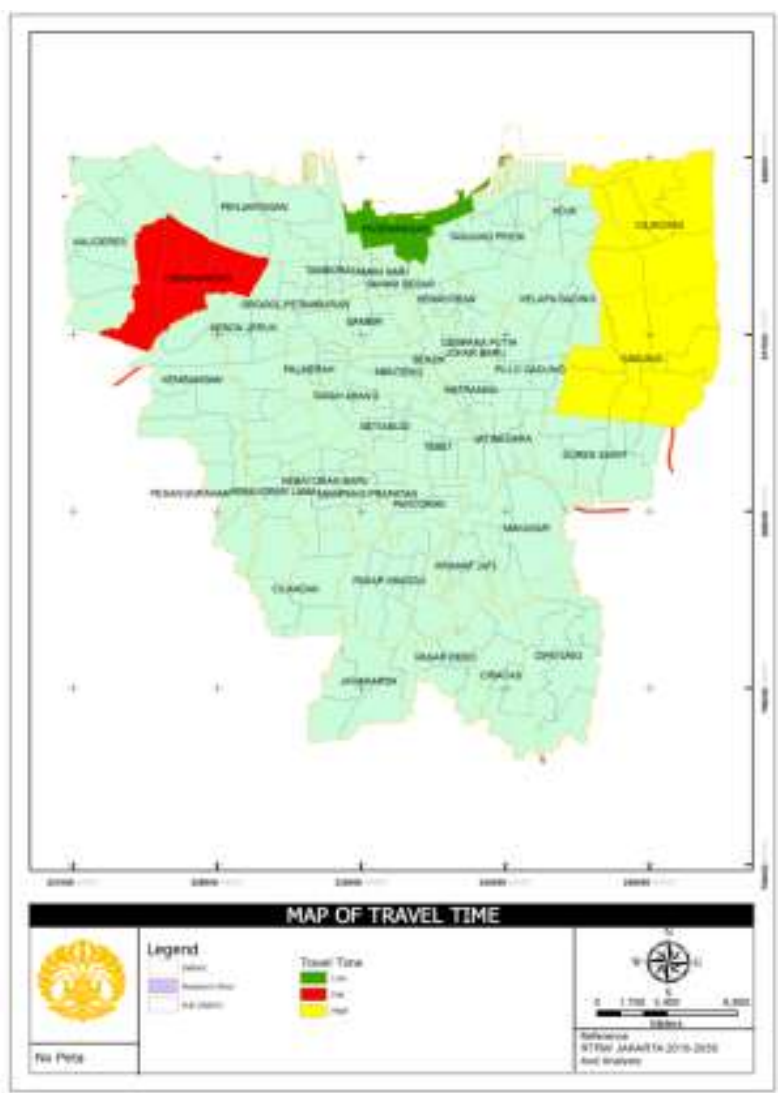

Figure 2.h Basic Map of Travel Time

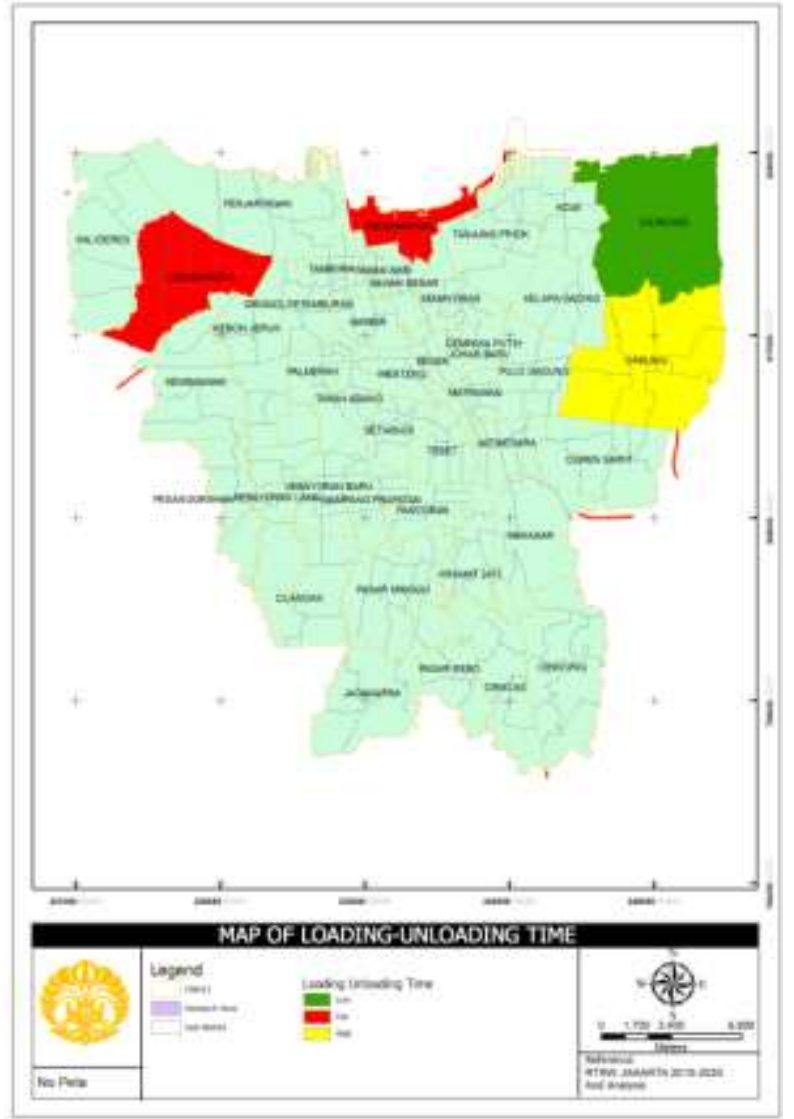

Figure 2.i Basic Map of Loading-Unloading Time

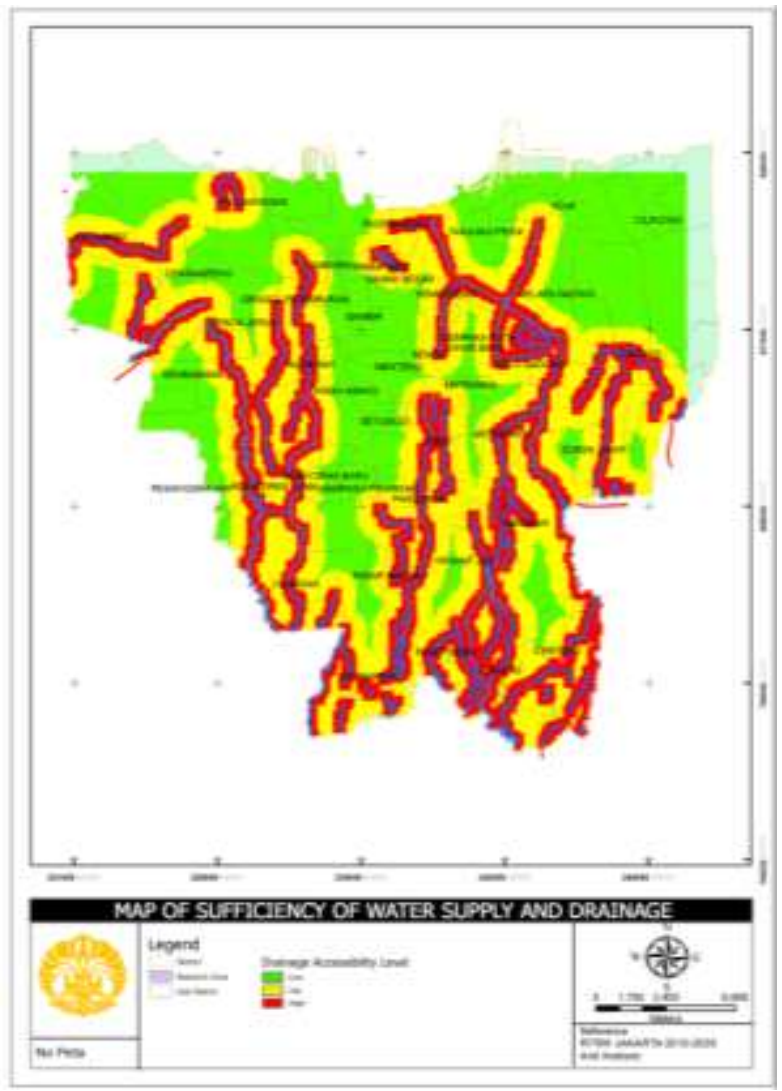

Figure 2.j Basic Map of Sufficiency of Water Supply and Drainage 


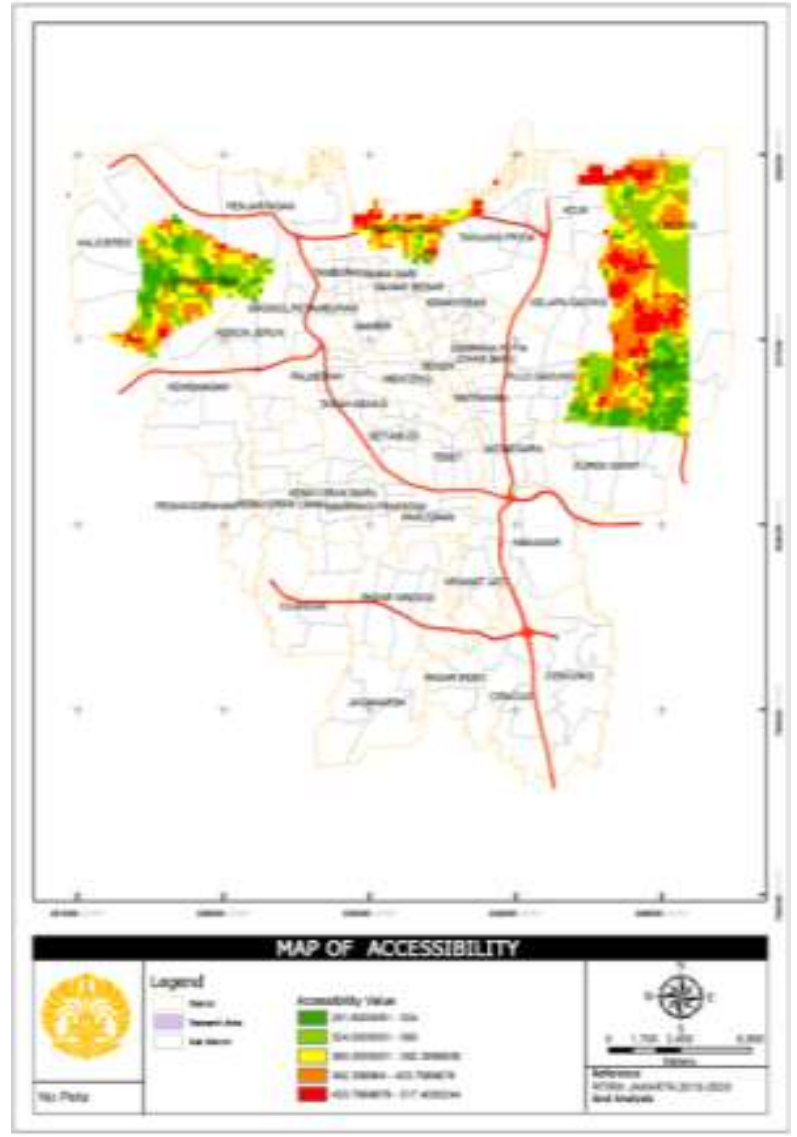

Figure 3a. Grid Map of Accessibility

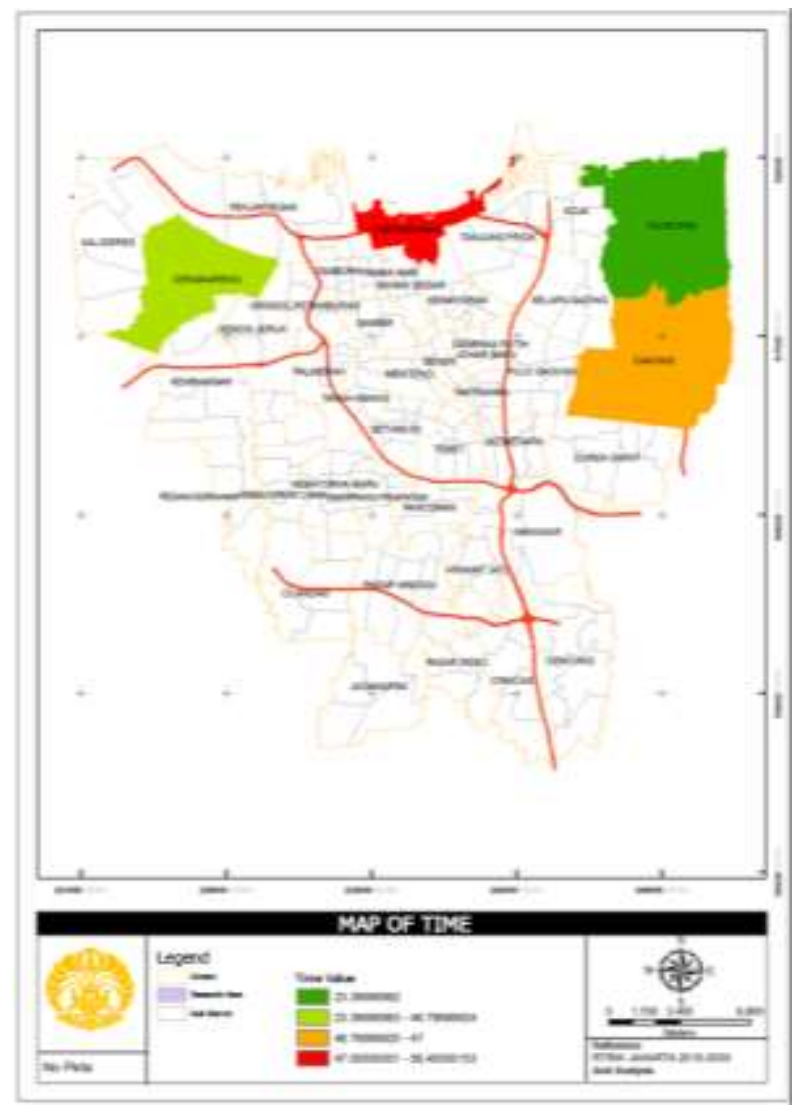

Figure 3b. Grid Map of Time

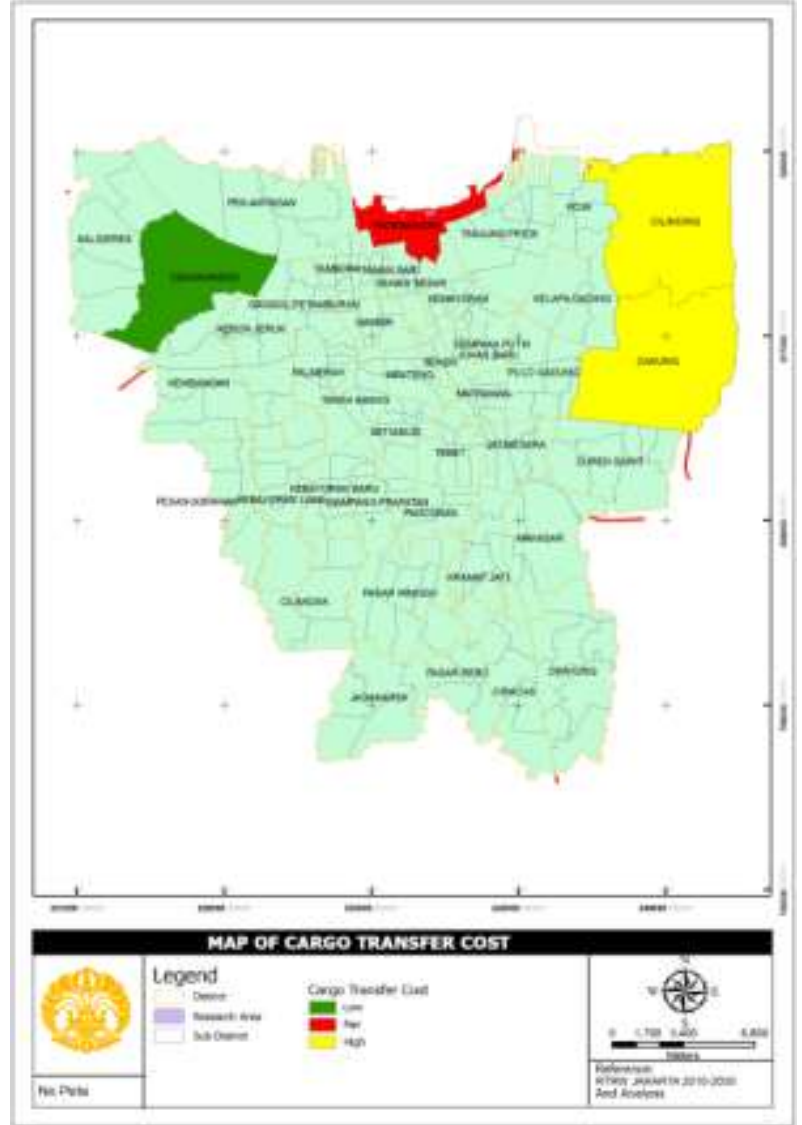

Figure 3c. Grid Map of Cost

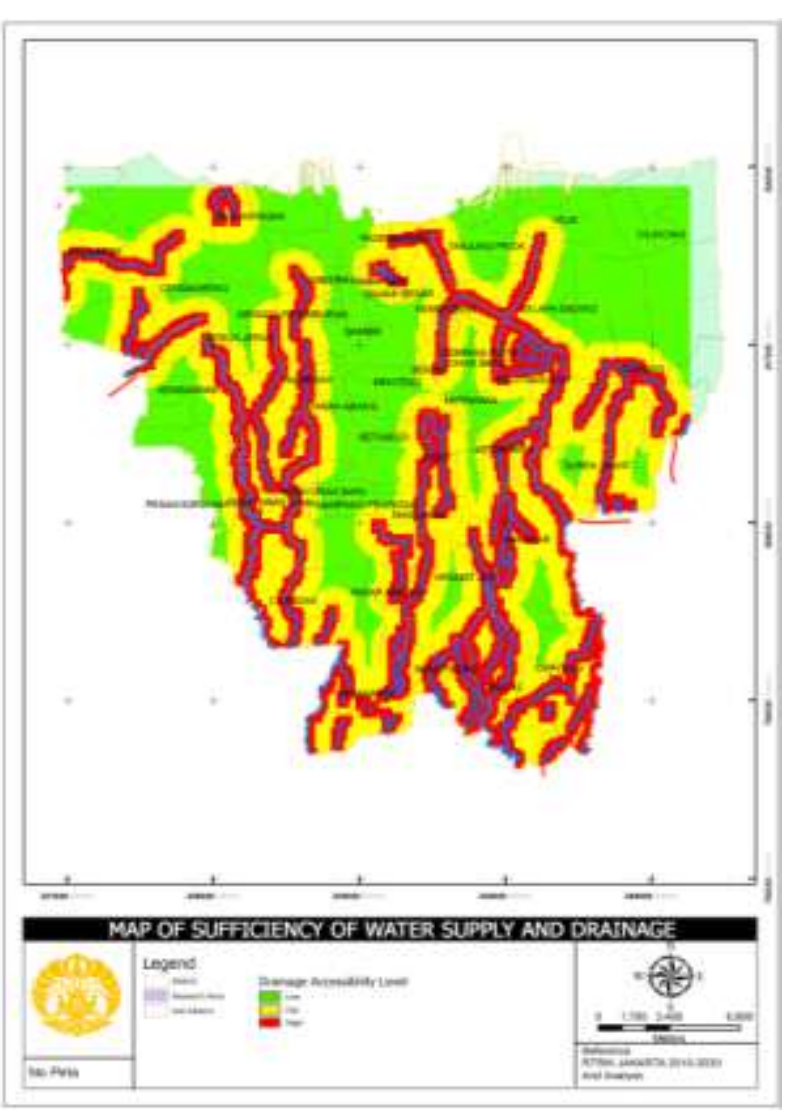

Figure 3d. Grid Map of Environment 


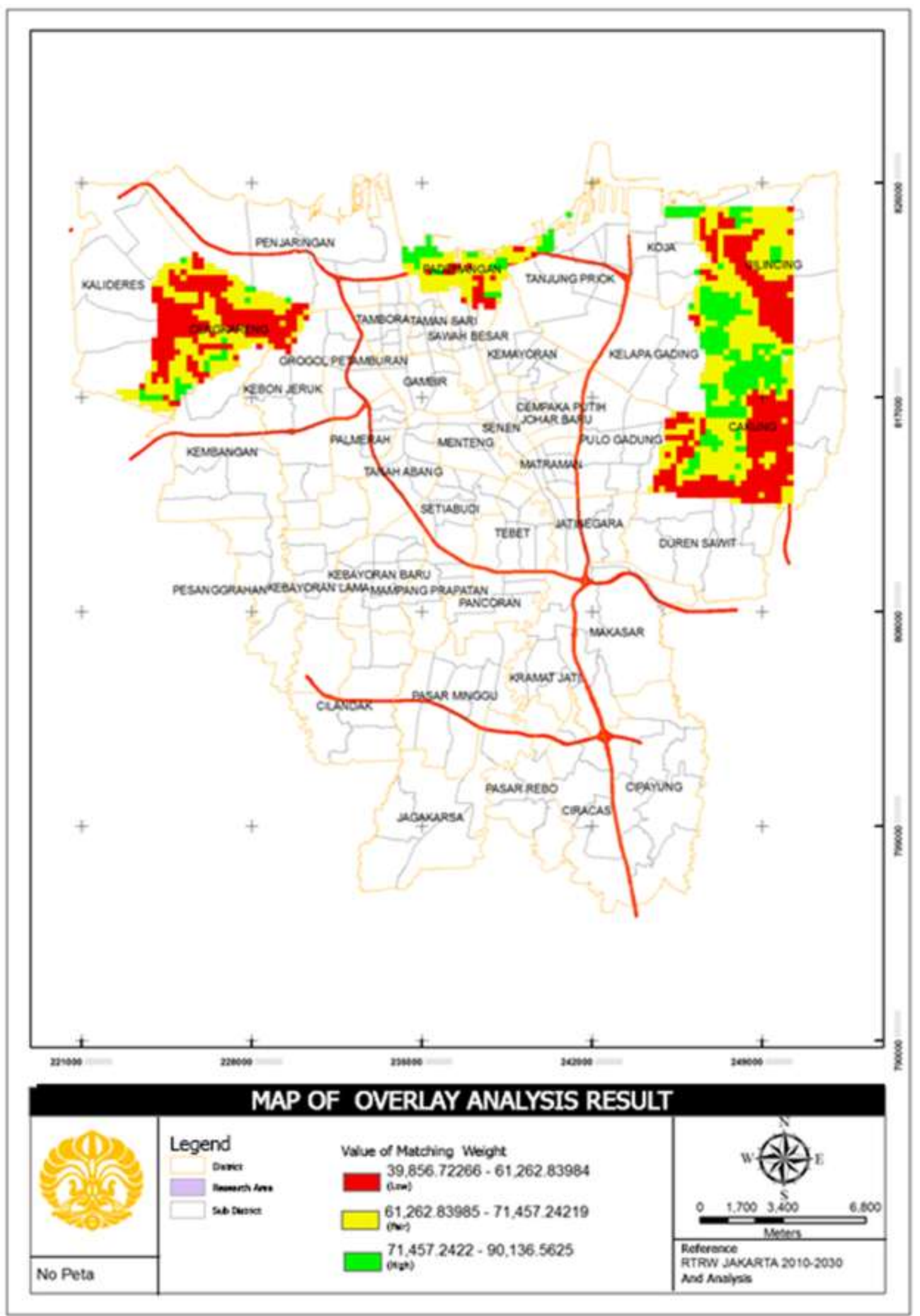

Figure 4. Final Map of OverlayAnalysis 
Table 4. Suitabilityof the Alternative Sites

\begin{tabular}{|c|c|c|c|c|c|c|}
\hline No & Alternative Site & Level of Suitability & $\begin{array}{c}\text { Proportion of } \\
\text { area }\end{array}$ & $\begin{array}{c}\text { Mid Value of } \\
\text { Suitability } \\
\text { Weight }\end{array}$ & Suitability Value & $\begin{array}{c}\text { Total } \\
\text { Suitability } \\
\text { Value }\end{array}$ \\
\hline \multirow[t]{3}{*}{1} & Pulo gebang & Low (1) & 0.42 & 50 & 21.19 & \\
\hline & & Fair (2) & 0.36 & 65 & 23.76 & 61.80 \\
\hline & & High (3) & 0.211 & 80 & 16.86 & \\
\hline \multirow[t]{3}{*}{2} & Rawa Buaya & Low (1) & 0.49 & 50 & 24.71 & \\
\hline & & Fair (2) & 0.45 & 65 & 29.54 & 58.36 \\
\hline & & High (3) & 0.051 & 80 & 4.11 & \\
\hline \multirow{3}{*}{3} & & Low (1) & 0.29 & 50 & 14.71 & \\
\hline & Tanah Merdeka & Fair (2) & 0.49 & 65 & 31.97 & 63.79 \\
\hline & & High (3) & 0.21 & 80 & 17.11 & \\
\hline \multirow[t]{3}{*}{4} & Lodan & Low (1) & 0.14 & 50 & 6.85 & \\
\hline & & Fair (2) & 0.63 & 65 & 40.82 & 66.47 \\
\hline & & High (3) & 0.23 & 80 & 18.79 & \\
\hline
\end{tabular}

\section{Conclusion}

The overlay analysis using ArcGIS has been applied to determine the best location of freight distribution terminal in Jakarta. The result shows that the four alternative sites are ranked as follows (from the best one): Lodan, Tanah Merdeka, Pulo Gebang, and Rawa Buaya. The ranking is determined based on cost factor (i.e. cargo transfer cost), accessibility factor (i.e. congestion, distance between terminal and market, distance between terminal and supplier, access and circulation in port and intermodal terminal, arterial and toll road level of service, access from terminal gate to the road), time factor (i.e. travel time and loading-unloading time), and environment factor (i.e. sufficiency of water supply and drainage).Those factors are derived from Likert Analysis on survey directed to freight terminals users. In order to refine this study result, further analysis may be required by taking into account the disused location factors due to the simplification done in this study.

\section{References}

1. Alan, L., Fell, M., and Douglas, C., Freight Consolidation Centre Study, London, Department for Transport, 2010.

2. Browne, M., Sweet, M., Woodburn, A., and Allen, J., Urban Freight Consolidation Centres, London, Report of Transport Studies Group University of Westminster, 2005.

3. Marinov, M., Zunder, T., and Islam, D.M.Z., Urban Freight Consolidation Concepts: Is There Something Missing, Newcastle: Newcastle University, 2008.
4. Munuzuri, J., Larraneta, J, Onieva, L, and Cortes, P., Solutions Applicable by Local Administrations for Urban Logistics Improvement, Cities, 2005, 22(1), pp. 15-28.

5. Daskin, M.S., Network and Discrete Location. Model, Algorithms, and Applications, Wiley Inter-Science, 1995

6. Anastasia, N., Lieyanto, Y., and Wongosari, F., Analisa Faktor-faktor yang Dipertimbangkan Konsumen dalam Pembelian Properti di Citra Raya Surabaya, Civil Engineering Dimension, 2005, 7(2), pp. 75 - 80.

7. Nugraha, P., Kusumo, S.T., and Setiawan, F., Peninjauan Faktor-faktor Penentu Rumah-Toko di Surabaya dari Sudut Pandang Pengembang dan Pengguna, Dimensi Teknik Sipil, 2000, 2(2), pp. 111-115.

8. Portugal, Da Silva, L., Morgano, A.V., and Junior, O.L., Location of Cargo Terminals in Metropolitan Areas of Developing Countries: Brazilian Case, Journal of Transport Geography, 2011, 19, pp. 900- 910.

9. Taniguchi, E., City Logistics Network Modeling and Intelligent Transport Systems, Pergamon, 2001.

10. Ogden, K.W., Urban Goods Movements: A Guide to Policy and Planning, Brookfield: Ashgate Pub Company, 1992.

11. Menteri Perhubungan Republik Indonesia, Keputusan Menteri Perhubungan Republik Indonesia Nomor 31 Tahun 1995 tentang Terminal Transportasi Barang.

12. Nazir, M., Metode Penelitian, Ghalia Indonesia, Bogor, 2005.

13. Prahasta, E., Tutorial ArcGIS Desktop untuk Bidang Geodesi dan Geomatika, Penerbit Informatika, Bandung, 2011. 